\title{
Pengembangan Sistem Informasi Seminar dan Skripsi Mahasiswa
}

\author{
Febrianto Sabirin ${ }^{1}$, Dewi Sulistiyarini ${ }^{2}$, Zulkarnain ${ }^{3}$. \\ ${ }^{1,2,3}$ Program Studi Pendidikan Teknologi Informasi dan Komputer, IKIP PGRI Pontianak \\ email: rinakasaka@gmail.com ${ }^{1}$,dhewysulis@gmail.com², freezulkarnain@gmail.com
}

(Received: 20 April 2020/ Accepted: 1 Juni 2020 / Published Online: 20 Juni 2020)

\begin{abstract}
Abstrak
Skripsi merupakan tahapan akhir dalam proses perkuliahan, namun belum tersedia sistem yang memadai untuk mendata pelaksanaan skripsi di IKIP PGRI Pontianak. Penelitian ini bertujuan untuk mengembangkan, menguji kelayakan, dan melihat respon pengguna dari Sistem Informasi Seminar dan Skripsi. Model pengembangan yang digunakan dalam pengembangan Sistem Informasi Seminar dan Skripsi adalah ADDIE dengan instrumen penelitian berupa wawancara dan angket. Teknik analisis data menggunakan statistik deskriptif untuk menggambarkan proses pengembangan sistem, kelayakan sistem, dan respon pengguna terhadap sistem yang dikembangkan. Sistem Informasi Seminar dan Skripsi dikembangkan menggunakan HTML, PHP, MySQL dan framework Bootstrap. Pengguna Sistem Informasi Seminar dan Skripsi terdiri dari lima aktor yaitu pengguna umum, mahasiswa, staf pemeriksaan, staf penjadwalan, dan admin. Hasil pengujian ahli sistem informasi dan respon pengguna sistem menunjukkan bahwa Sistem Informasi Seminar dan Skripsi berada pada kategori sangat baik, sehingga sistem Informasi yang telah dikembangkan ini dapat diaplikasikan untuk mendata skripsi pada keadaan nyata di IKIP PGRI Pontianak.
\end{abstract}

Kata Kunci: ADDIE, Sistem Informasi, Skripsi

\begin{abstract}
Thesis is the final stage in the lecture process, but there is not yet an adequate system to record the implementation of the thesis at IKIP PGRI Pontianak. This study aims to develop, test the feasibility, and see the user's response from the Seminar and Thesis Information System. The development model used in the development of Seminar, and Thesis Information Systems is ADDIE with research instruments in the form of interviews and questionnaires. Data analysis techniques use descriptive statistics to define the process of system development, system feasibility, and user response to the system. Seminar and Thesis Information System were developed using HTML, PHP, MySQL and the Bootstrap framework. Users of Seminar and Thesis Information Systems consist of five actors, namely general users, students, examination staff, scheduling staff, and admins. The test results from Information system experts and response from users indicate that Seminar and Thesis Information Systems are in the very good category so that the information system that has been developed can be applied to record the thesis in a real situation in IKIP PGRI Pontianak.
\end{abstract}

Keywords: ADDIE, Information System, Thesis

\section{PENDAHULUAN}

Teknologi informasi merupakan teknologi hasil penggabungan antara komputasi dan jalur komunikasi kecepatan tinggi yang membawa data, suara, dan video (Williams \& Sawyer, 2003). Teknologi informasi digunakan untuk menyimpan informasi, sehingga membantu dalam memberikan informasi secara cepat dan tepat. Penggunaan teknologi informasi telah merambah dibidang pendidikan, baik dalam mendukung kegiatan pembelajaran mauapun kegiatan administrasi (Majid, Ridwan, Setiadi, \& Nurdiyanto, 2018; Saxena, 2017). Manfaat teknologi informai dalam bidang pendidikan antara lain meningkatkan layanan pendidikan, mempermudah pengumpulan dan penyebaran informasi 
pendidikan, media peyimpanan data pendidikan, meningkatkan keterampilan mengajar, memotivasi peserta didik, hingga membantu kegiatan komunikasi dalam pendidikan(Saxena, 2017). Untuk itu penggunakan teknologi informasi tidak hanya di ruang kelas tetapi diberbagai aspek pendidikan, penggunaan teknologi informasi juga perlu diterapkan (Hernandez, 2017).

Institut Keguruan dan Ilmu Pendidikan Persatuan Guru Republik Indonesia (IKIP PGRI) Pontianak sebagai penyelenggara pendidikan tinggi saat ini telah mengimplementasikan penggunaan teknologi informasi dalam mendukung berbagai aspek pendidikan. Meskipun demikian masih terdapat beberapa layanan, khususnya yang bersifat administratif yang belum sepenuhnya didukung oleh teknologi informasi. Menurut penelitian yang dilakukan, salah satu pelayanan administrasi yang dapat ditingkatkan dengan mengaplikasikan teknologi informasi di IKIP PGRI Pontianak khususnya di tingkat Program Studi adalah proses pendaftaran dan pendataan terkait seminar dan skripsi mahasiswa (Sulistiyarini \& Sabirin, 2018).

Skripsi menurut Panduan Akademik IKIP PGRI Pontianak adalah karya ilmiah bagi mahasiswa IKIP PGRI Pontianak yang menerapkan kaidah-kaidah ilmiah dalam melakukan penelitian khususnya dalam bidang pendidikan (IKIP PGRI Pontianak, 2017). Lebih lanjut dalam Panduan Akademik IKIP PGRI Pontianak disebutkan bahwa dalam menyusun skirpsi, mahasiswa IKIP PGRI Pontianak perlu menyusun desain skripsi yang nantinya diujikan dalam bentuk seminar desain skripsi sebelum melaksanakan penelitian, dan melaksanakan sidang skripsi setelah penelitian dilaksanakan (IKIP PGRI Pontianak, 2017).

Pendataan skripsi merupakan bagian penting yang perlu diperhatikan IKIP PGRI Pontianak selaku penyelenggara pendidikan tinggi. Melalui pendataan skripsi yang baik, pihak IKIP PGRI Pontianak dapat menyusun berbagai strategi terutama terkait dengan masa studi mahasiswa, arah penelitian mahasiswa, hingga menghindari plagiasi dari skripsi mahasiswa. Namun demikian, menurut penelitian yang dilakukan diketahui bahwa pendataan skripsi khususnya sidang dan seminar pada tingkat Program Studi belum menerapkan sistem yang memadai, dimana data-data skripsi hanya disimpan menggunakan aplikasi pengolah angka dan aplikasi pengolah kata yang proses pendataannya sangat tergantung oleh staf dilingkungan program studi (Sulistiyarini \& Sabirin, 2018). Padahal penggunaan sistem informasi dibidang akademik merupakan kebutuhan mutlak bagi pelayanan pendidikan sehingga memberikan kemudahan dalam proses administrasi dan akademik (Fitrianah \& Sucahyo, 2012), lebih lanjut penggunaan sistem informasi akan membantu memberikan data yang akurat kepada pihak penyelenggara pendidikan, peserta didik, orang tua, ataupun masyarakat (Susanti, 2016).

Proses pendataan skripsi ditingkat Program Studi IKIP PGRI Pontianak sendiri merupakan proses yang cukup panjang dan prosedural. Proses pendataan skripsi melewati berbagai tahapan dan pemeriksaan berbagai berkas. Proses pendataan skripsi dimulai dengan permohonan pembimbing, dimana mahasiswa secara individu perlu menghadap Pimpinan Program Studi untuk memperoleh data terkait pembimbing skripsi, dilanjutkan dengan pengajuan judul penelitian, pemeriksaan berkas-berkas untuk melaksanakan seminar desain skripsi atau sidang skripsi, hingga penentuan jadwal seminar desain skripsi atau sidang skripsi. Seluruh proses tersebut perlu dilakukan mahasiswa dengan cara bertemu langsung dengan pimpinan dan staf di program studi. Permasalahan yang terjadi adalah Pimpinan Program Studi tidak selalu ada ditempat dikarenakan memiliki berbagai tugas lainnya, sedangkan untuk staf program studi hanya dapat menangani satu orang mahasiswa dalam satu waktu sedangkan proses pemeriksaan memakan waktu yang cukup lama sehingga mahasiswa perlu mengantri untuk melakukan proses pendataan skripsi.

Mengatasi permasalahan terkait pendataan skripsi mahasiswa di IKIP PGRI Pontianak, khususnya pada tingkat program studi maka diperlukan penelitian untuk membangun atau 
mengembangkan sistem informasi pendataan seminar dan skripsi. Penggunaan sistem informasi ditujukan untuk otomatisasi kegiatan manajemen rutin dan administratif (Demoč, Vyhnáliková, \& Aláč, 2015). Menurut penelitan yang telah dilakukan, sistem informasi tugas akhir mahasiswa merupakan bagian penting bagi pendidikan tinggi dalam membantu proses pendataan dan monitoring pengerjaan tugas akhir mahasiswa (Muftia, Negara, \& Safiradi, 2015; Ramayasa \& Arnawa, 2015). Melalui pengembangan Sistem Informasi Seminar dan Skripsi akan membantu program studi dalam mendata skripsi yang sedang berjalan ataupun yang telah selesai, mempercepat pekerjaan staf program studi karena proses pemeriksaan akan dibantu oleh sistem, dan mempermudah mahasiswa dalam kegiatan seminar dan skripsi yang akan ditempuh. Untuk itu sebagai pedoman dalam penelitian pengembangan Sistem Infomrasi Seminar dan Skripsi, terdapat tiga tujuan yaitu: 1) menghasilkan Sistem Informasi Seminar dan Skripsi yang sesuai dengan lingkungan IKIP PGRI Pontianak; 2) menguji kelayakan sistem informasi yang dihasilkan; dan 3) melihat respon pengguna dari sistem informasi yang dihasilkan.

\section{METODE}

Bagian ini memaparkan metode yang digunakan dalam penelitian yaitu metode Research and Development $(R \& D)$. $\mathrm{R} \& \mathrm{D}$ adalah metode yang digunakan untuk menghasilkan sebuag produk dan kemudian menguji keefektifan produk tersebut(Sugiyono, 2009). Model pengembangan yang digunakan dalam penelitian ini model ADDIE (Analysis, Design, Development, Implementation, and Evaluation). Tahapan ADDIE terdiri dari tahapan analisis, desain, pengembangan, dan implementasi dimana pada tiap tahapan akan dilakukan evaluasi sebelum masuk ketahap selanjutnya. Adapun gambaran model ADDIE dapat dilihat pada gambar 1 .

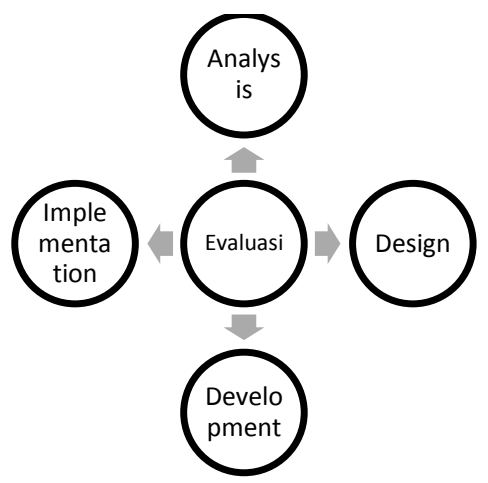

Gambar 1. Model ADDIE

Subjek penelitian terdiri dari subjek pengembangan yang berjumlah 2 orang ahli sistem informasi dan subjek ujicoba yang berjumlah 30 orang terdiri dari 26 mahasiswa dan 4 staf. Teknik pengumpulan data berupa wawancara, dan angket. Wawancara digunakan untuk mendapatkan data tentang hal apa saja seperti data input, proses, dan output yang dibutuhkan untuk membangun produk berupa sistem informasi berbasis web. Jenis wawancara yang digunakan adalah wawancara terbuka. Angket digunakan untuk memberikan penilaian validitas produk, antara lain angket untuk ahli sistem informasi, dan angket respon pengguna. Jenis angket yang digunakan adalah angket tertutup dimana responden diberi kesempatan untuk memberi jawaban pada kolom yang sudah ditentukan dan diberi nilai. Indikator yang digunakan untuk mengukur respon pengguna sistem informasi yaitu usability, functionality, dan visual communication. Teknik analisis data yang digunakan yaitu teknik analisis deskriptif dengan mencari nilai persentasi dari tiap indikator instrumen. 


\section{HASIL DAN PEMBAHASAN}

\section{Hasil}

Hasil analisis pengguna dan kebutuhan pengguna menunjukkan bahwa sistem yang dihasilkan haruslah mudah diakses oleh banyak pengguna dan memiliki portabilitas yang tinggi dan merupakan teknologi yang telah familiar digunakan, untuk itulah sistem informasi yang dikembangkan merupakan sistem informasi berbasis website. Dari hasil analsis calon pengguna terdapat lima aktor Sistem Informasi Seminar dan Skripsi yaitu pengguna umum, mahasiswa, staf pemeriksaan, staf penjadwalan, dan admin. Aktor pengguna umum dapat berupa mahasiswa, dosen, orang tua, maupun masyarakat. Aktor mahasiswa adalah mahasiswa dilingkungan IKIP PGRI Pontianak yang mengambil mata kuliah skripsi. Aktor staf dibagi menjadi dua bagian yaitu staf yang bertugas untuk melakukan pemeriksaan berkas, dan staf yang bertugas untuk menyusun penjadwalan. Terakhir adalah aktor admin yang bertugas mengelola data master dari sistem. Setiap aktor memiliki aksi yang berbeda namun tetap terhubung dalam sistem, adapun gambaran dari aksi dari tiap-tiap aktor dalam Sistem Informasi Seminar dan Skripsi dapat dilihat pada gambar 1.

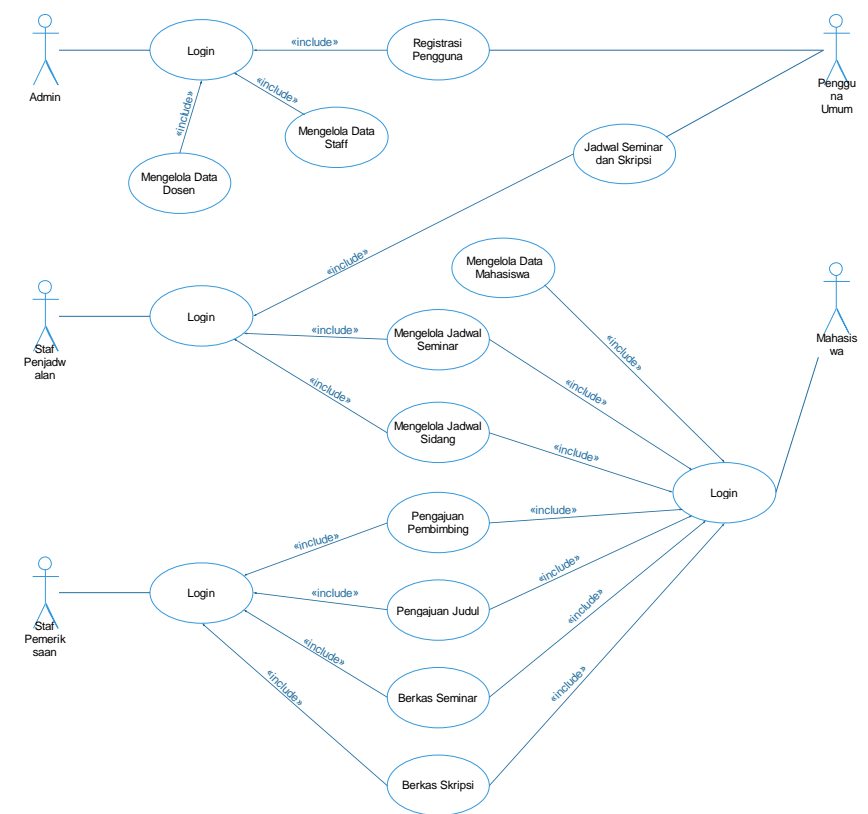

Gambar 1. Use Case Diagram Sistem Informasi Seminar dan Skripsi

Berdasarkan Use Case Diagram Sistem Infomrasi Seminar dan Skripsi, aktor pengguna umum hanya dapat melihat data berupa jadwal seminar dan skripsi. Mengingat bahwa pelaksanaan seminar dan skripsi di IKIP PGRI Pontianak adalah bersifat terbuka, dengan adanya informasi terkait jadwal seminar dan skripsi, pengguna umum dapat mengetahui informasi terkait pelaksanaan seminar dan skipsi yang ada dilingkungan IKIP PGRI Pontianak. Adapun halaman jadwal seminar dan skripsi dapat dilihat pada gambar 2 .

Pengguna umum yang ingin masuk ke dalam sistem perlu mendaftarkan diri atau melakukan registrasi. Mengingat Sistem Informasi Seminar dan Skripsi merupakan sistem yang dikhususkan untuk mahasiswa IKIP PGRI Pontianak yang mengambil mata kuliah Skripsi, maka tidak sembarang orang atau mahasiswa dapat terdaftar di sistem. Untuk itu, pengguna umum yang ingin mendaftarkan diri akan diverifikasi oleh admin dengan menyesuaikan dengan data master yang ada, apabila terdapat kesalahan atau ketidaksesuaian dengan data master maka pengguna umum tersebut tidak dapat terdaftar pada sistem.

Tugas admin selain memverifikasi pengguna umum yang mendaftar ke Sistem Informasi Seminar dan Skripsi adalah mengelola data master untuk sistem. Data master 
terdiri dari data mahasiswa yang diambil dari Sistem Informasi Akademik IKIP PGRI Pontianak, data dosen sebagai pembimbing dan penguji seminar atau sidang skripsi, dan data staf. Admin dapat menambahkan, menghapus, atau mengubah data master tersebut. Adapun tampilan halaman admin dapat dilihat pada gambar 3.

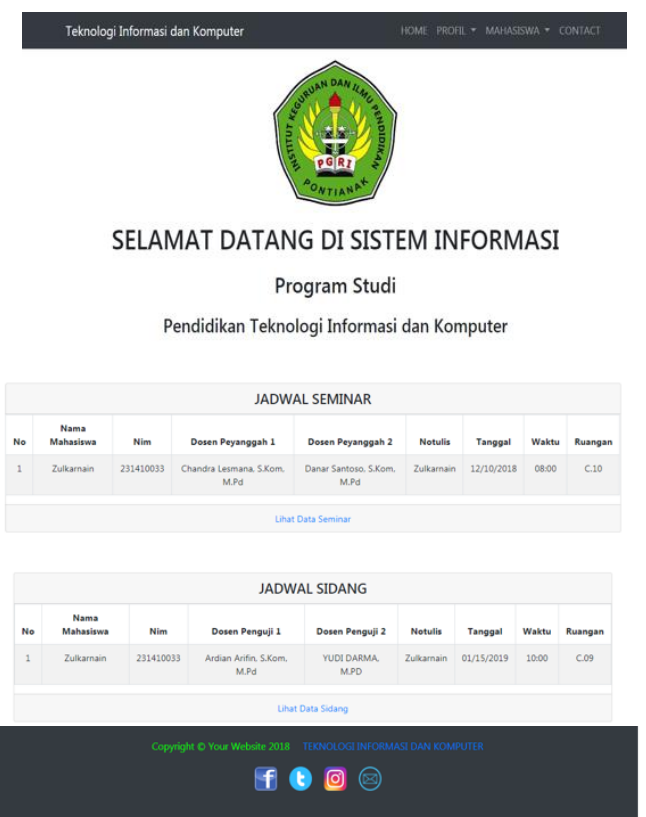

Gambar 2. Halaman Jadwal Seminar dan Sidang pada Sistem Informasi

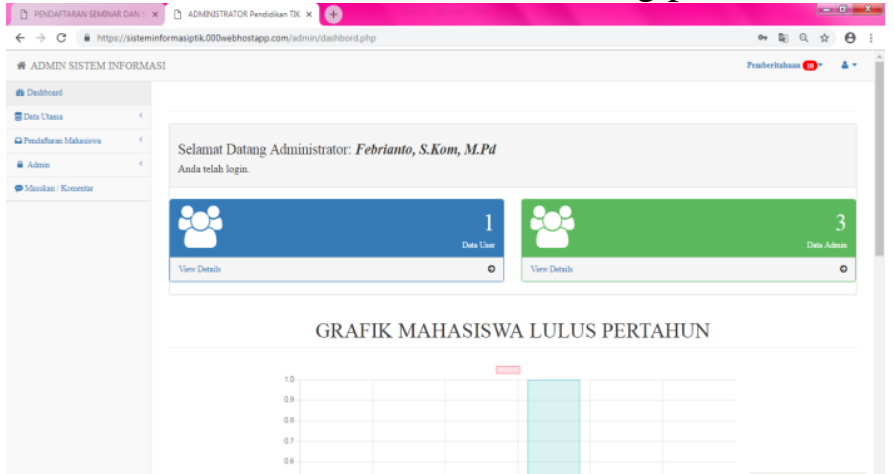

Gambar 3. Halaman Admin Sistem Informasi Seminar dan Skripsi

Mahasiswa IKIP PGRI Pontianak yang telah terdaftar ke dalam sistem dapat mengajukan permohonan pembimbing atau disebut dengan Rangkap 3 yang dilanjutkan dengan pengajuan judul penelitian atau disebut dengan Rangkap 5. Dalam pengajuan pembimbing skripsi mahasiswa perlu memasukkan data terkait nilai mata kuliah prasyarat skripsi yang disertai dengan bukti pindai dari Kartu Hasil Studi. Data nilai tersebut selanjutnya akan diperiksa oleh staf pemeriksaan, apabila data telah sesuai maka mahasiswa dapat mencetak blanko permohonan pembimbing yang telah disediakan sistem. Untuk mengajukan judul penelitian, mahasiswa perlu mendapatkan pengesahan dari blanko permohonan pembimbing yang dilengkapi dengan outline penelitian. Berkas-berkas tersebut perlu dipindai oleh mahasiswa dan diunggah ke sistem yang selanjutnya akan diperiksa oleh staf pemeriksaan. Adapun gambaran permohonan pembimbing dan pengajuan judul dapat dilihat pada gambar 4.

Mahasiswa IKIP PGRI Pontianak yang ingin melakukan seminar desain skripsi ataupun sidang skripsi dapat melakukan pendaftaran melalaui Sistem Informasi Seminar dan Skripsi. Secara umum proses pendaftaran seminar desain skripsi dan sidang skripsi adalah 
sama, yang membedakan hanyalah dokumen yang perlu dilengkapi. Untuk melakukan pendaftaran seminar desain penelitian atau sidang skripsi, mahasiswa perlu memindai berkas yang menjadi syarat seminar atau sidang dan mengunggah berkas tersebut ke dalam sistem. Staf pemeriksaan selanjutnya akan memeriksa berkas yang telah masuk, apabila berkas dinyatakan lengkap maka staf penjadwalan dapat menjadwalkan pelaksanaan seminar ataupun sidang mahasiswa. Setelah jadwal seminar atau sidang ditentukan oleh staf penjadwalan maka mahasiswa dapat mencetak blanko seminar ataupun skripsi untuk kemudian diajukan ke BAA IKIP PGRI Pontianak. Adapun proses pendaftaran seminar dan sidang dapat dilihat pada Gambar 5.

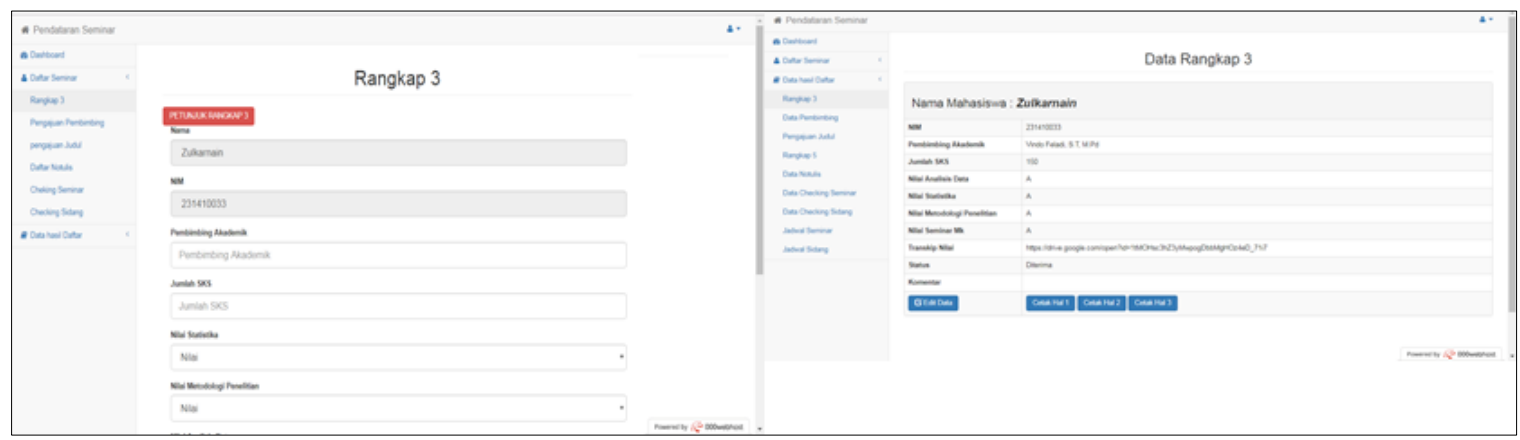

Gambar 4. Halaman Permohonan Pembimbing Sistem Informasi Seminar dan Skripsi

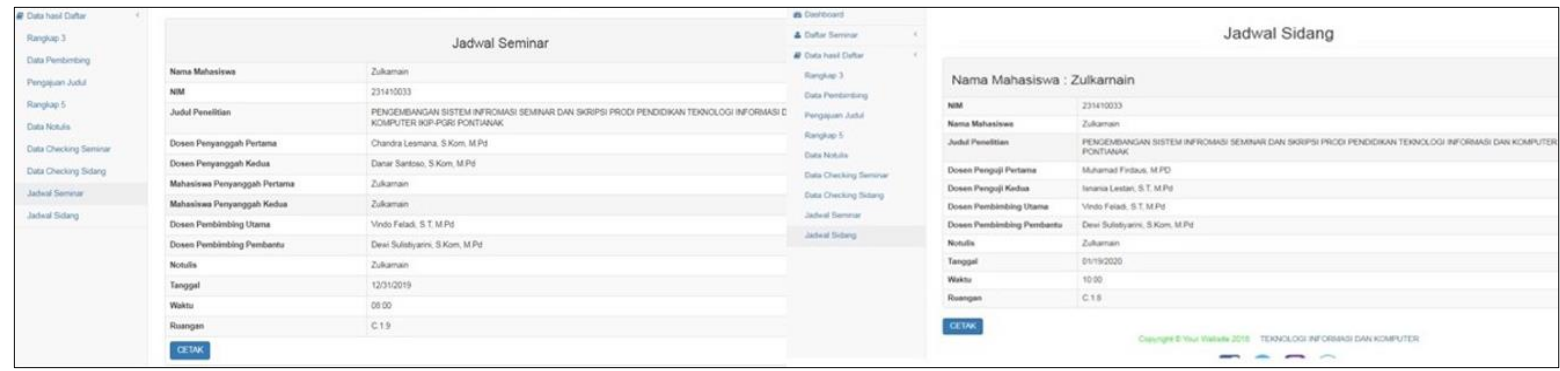

Gambar 5. Halaman Penjadwalan Seminar dan Sidang Skripsi

Sistem informasi yang telah dikembangkan selanjutnya dilakukan pengujian untuk melihat kualitas dari sistem. Pengujian sistem dilakukan oleh ahli dibidang sistem informasi dan pengguna. Ahli yang menguji sistem terdiri dari 2 orang dan untuk pengujian pengguna melibatkan 30 orang yang terdiri dari 26 mahasiswa dan 4 orang staf. Adapun hasil pengujian ahli dapat dilihat pada tabel 1, sedangkan hasil pengujian pengguna dapat dilihat pada tabel 2 dan gambar 6.

Tabel 1. Hasil Validasi Sistem Informasi Seminar dan Skripsi

\begin{tabular}{ccccc}
\hline Ahli Media & Manfaat & Desain & Pengoperasioan & Rata-Rata \\
\hline $\mathbf{1}$ & 4,78 & 4,00 & 4,28 & 4,39 \\
$\mathbf{2}$ & 4,33 & 4,22 & 4,57 & 4,28 \\
Rata-Rata & 4,56 & 4,11 & 4,43 & 4,33 \\
Kriteria & Sangat Baik & Sangat Baik & Sangat Baik & Sangat Baik \\
\hline
\end{tabular}

Berdasarkan tabel 1, diketahui bahwa hasil pengujian Sistem Informasi Seminar dan Skripsi secara umum memiliki rata-rata sebesar 4,33 atau tergolong sangat baik. Hasil ini diperoleh dengan melihat aspek manfaat dari sistem yang dikembangkan dimana rata-rata para ahli memberikan skor sebear 4,56 atau tergolong sangat baik, sementara aspek desain rata-rata para ahli memberikan skor sebesar 4,11 atau tergolong sangat baik, dan aspek pengoperasian memperoleh skor sebesar 4,43 atau tergolong sangat baik. 


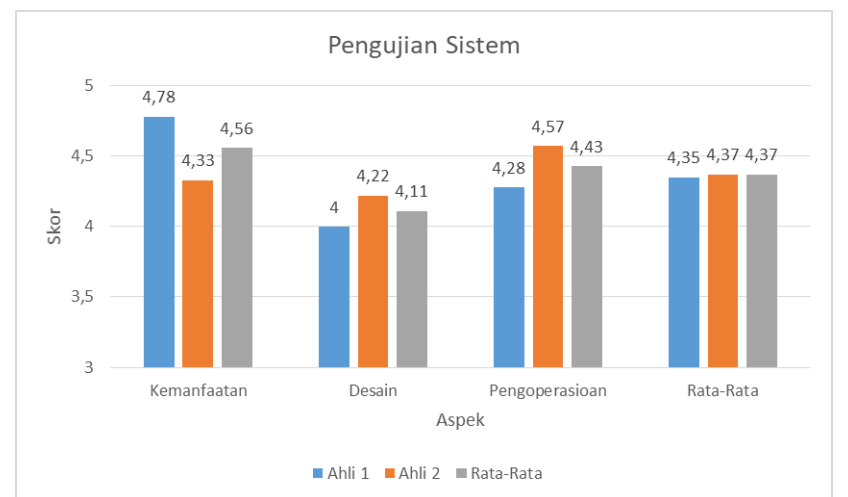

Gambar 6. Grafik Hasil Validasi Sistem Informasi Seminar dan Skripsi

Selanjutnya, pada tabel 2 dan gambar 7 diketahui secara umum respon pengguna berada pada skor rata-rata 4,43 atau masuk dalam kategori sangat baik terhadap Sistem Informasi Seminar dan Skripsi yang dibangun. Hasil ini diperoleh dari hasil pengukuran tiga aspek yaitu aspek usability, functionality, dan visual communication. Pada aspek usability rata-rata skor yang diperoleh adalah 4,41 atau masuk kategori sangat baik, sementara pada aspek functionality rata-rata skor yang diperoleh adalah 4,49, dan terakhir pada aspek visual communication memperoleh rata-rata skor adalah 4,42 atau masuk dalam kategori sangat baik.

Tabel 2. Hasil Data Respon Pengguna Sistem Informasi Seminar dan Skripsi

\begin{tabular}{lcl}
\hline Aspek & Rata - Rata & Kriteria \\
\hline Usability & 4.41 & Sangat Baik \\
Functionality & 4.49 & Sangat Baik \\
Visual Communication & 4.42 & Sangat Baik \\
Rata-Rata & 4.43 & Sangat Baik \\
\hline
\end{tabular}

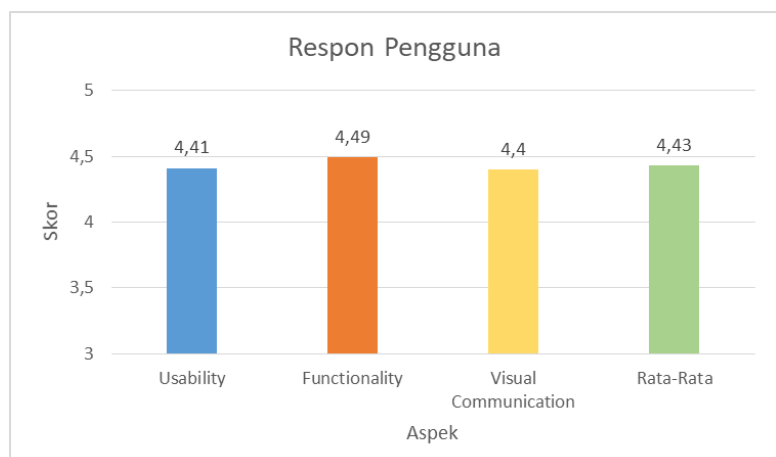

Gambar 7. Grafik Respon Pengguna Sistem Informasi Seminar dan Skripsi

\section{Pembahasan}

Sistem Informasi Seminar dan Skripsi merupakan sistem informasi berbasis website. Pemilihan sistem informasi berbasis web dipilih berdasarkan analisis kebutuhan dari calon pengguna dimana pengguna menginginkan sistem yang memiliki portabilitas dan fleksilibitas yang tinggi. Penggunaan sistem informasi berbasis website telah banyak diaplikasi diberbagai bidang dengan memberikan layanan berupa kecepatan, ketepatan, dan akurasi (Wahyuniardi, Afrianti, Nurjaman, \& Gusdya, 2016), penggunaan sistem informasi berbasis website dapat menghilangkan kendala tempat dan waktu operasi sistem (Hidayat, Hartono, \& Sukiman, 2017), dan perkembangan smartphone mendorong penggunaan sistem berbasis website berkembang dengan pesat (Nur'Ainun, Hartono, \& Jimmy, 2017). Oleh karena Sistem 
Informasi Seminar dan Skripsi merupakan sistem informasi berbasis website maka sistem ini dapat diakses kapan pun dan dimana pun selama terdapat akses internet melalui berbagai perangkat mulai dari komputer, laptop, hingga smartphone.

Berangkat dari analisis kebutuhan sistem, selanjutnya Sistem Informasi Seminar dan Skripsi didesain menggunakan Unified Modelling Language (UML). UML dapat menjabarkan secara rinci kebutuhan sistem yang akan dibangun (Suendri, 2018), penggunaan UML juga dapat membantu membangun sistem yang lebih efektif dan efisien (Wati \& Kusumo, 2016). Berdasarkan UML Sistem Informasi Seminar dan Skripsi diketahui bahwa sistem memiliki lima aktor yaitu pengguna umum, admin, mahasiswa, staf pemeriksaan, dan staf penjadwalan. Selain aktor Pengguna Umum, aktor lainnya perlu melakukan login untuk dapat masuk ke dalam sistem, hal ini dikarenakan aktor selain pengguna umum dapat menambahkan, mengubah, menghapus, dan melihat data ke dalam sistem, sedangkan Pengguna Umum hanya dapat meilihat data saja. Namun, apabila aktor Pengguna Umum adalah mahasiswa yang telah mengambil mata kuliah Skripsi maka dapat mendaftarkan diri ke sistem dan akan diverifikasi oleh aktor Admin dengan memeriksa data master mahasiswa. Selain bertugas memverifikasi Pengguna Umum yang ingin mendaftar ke sistem, aktor Admin juga bertugas dalam mengelola data master dari sistem yang terdiri dari data staf, data dosen, dan data mahasiswa. Mahasiswa yang telah terdaftar di sistem dapat mengajukan pembimbing skripsi, judul penelitian/skripsi, pelaksanaan seminar, dan pelaksanaan sidang skripsi. Agar ajuan yang dilakukan oleh aktor Mahasiswa dapat diproses, maka perlu dilengkapi dengan berkas pendukung yang nantinya akan diverifikasi oleh staf pemeriksaan, dan dilanjutkan oleh staf penjadwalan khusus untuk menjadwalkan pelaksanaan seminar desain skripsi ataupun sidang skripsi.

Sistem Informasi Seminar dan Skripsi merupakan sistem informasi berbasis website, untuk itu pengembangan sistem ini menggunakan Hyper Text Markup Languange (HTML), PHP: Hypertext Preprocessor (PHP), dan MySQL yang didukung dengan framework Bootstrap. Penggunaan HTML, PHP, dan MySQL sebagai sistem informasi telah banyak diterapkan baik untuk bisnis (Mansur \& Kasmawi, 2017; Oluwatofunmi, Idowu, \& Izang, 2018) maupun untuk pendidikan (Dafitri, H., \& Elsera, 2017; Lukman, 2017; Surbakti \& Pasaribu, 2018). HTML dalam sistem ini merupakan fondasi dari sistem yang dibangun yang menghubungkan antar satu halaman dengan halaman lainnya dalam Sistem Informasi Seminar dan Skripsi, sementara PHP menjadikan website yang dibangun mampu mengolah data yang dimasukkan pengguna dan menghasilkan luaran yang diinginkan. Peneltian yang telah dilakukan menunjukkan bahwa PHP dapat digunakan sebagai pendukung HTML guna menghasilkan website yang mampu mengolah data (Janpla, Kularbphettong, Rattanachai, \& Tangtastham, 2015; Surbakti \& Pasaribu, 2018). MySQL merupakan sistem manajemen basis data yang bertugas sebagai penyimpanan data terpusat, dimana data tersebut dapat dapat diproses oleh sistem. Penggunaan basis data terpusat memiliki keunggalan berupa integritas data, keamanan, perawatan yang lebih mudah, kecepatan dalam akses, dan portabilitas (Connolly \& Begg, 2010).

Hasil dari pengembangan Sistem Informasi Seminar dan Skripsi dilakukan pengujian oleh ahli untuk melihat kelayakan sistem yang dihasilkan dan pengujian oleh pengguna untuk melihat respon dari pengguna. Berdasarkan pengujian yang dilakukan diketahui bahwa Sistem Informasi Seminar dan Skripsi tergolong sangat baik oleh ahli dan juga pengguna. Hasil ini sejalan dengan beberapa sistem informasi berbasis website khususnya dibidang pendidikan yang menunjukkan bahwa sistem informasi berbasis website pada bidang pendidikan layak digunakan dan mendapat respon yang baik dari pengguna (Dafitri, H., \& Elsera, 2017; Lubanga, Chawinga, Majawa, \& Kapondera, 2018; Sulindawaty, 2015). Hasil ini diperoleh juga sejalan penelitian yang dilakukan oleh (Satyahadewi \& Mutiah, 2019) yang menunjukkan sistem informasi monitoring tugas akhir berbasis web dapat membantu fakultas 
dalam pangkalan data dan rekam jejak tugas akhir mahasiswa, pencatatan seminar dan sidang mahasiswa .

\section{SIMPULAN}

Sistem Informasi Seminar dan Skripsi merupakan sistem informasi berbasis website yang berfungsi sebagai sarana pendataan, monitoring, dan evaluasi skripsi mahasiswa IKIP PGRI Pontianak. Desain sistem menunjukkan bahwa sistem ini terdiri dari satu aktor yang hanya membaca data yaitu pengguna umum dan empat aktor yang dapat menambahkan, menghapus, mengubah, dan membaca data yaitu admin, mahasiswa, staf pemeriksaan, dan staf penjadwalan. Pengembangan sistem dilakukan menggunakan HTML, PHP, dan MySQL yang didukung dengan framework Bootstrap. Hasil pengujian oleh ahli menunjukkan bahwa sistem yang dihasilkan berada pada kategori sangat baik, sementara hasil pengujian oleh pengguna juga menunjukkan respon yang sangat baik, sehingga sistem yang dihasilkan dapat diterapkan dalam lingkungan nyata di IKIP PGRI Pontianak.

\section{REFERENSI}

Connolly, T., \& Begg, C. (2010). Database System A Practical Approuch to Design, Implementation, and mangement. London: Pearson.

Dafitri, H., \& Elsera, M. (2017). Rancang Bangun Sistem Informasi Akademik Berbasis Web (Studi Kasus: SMA Swasta Harapan 1 Medan). QUERY: Jurnal Sistem Informasi, 1(2), 23-32.

Demoč, V., Vyhnáliková, Z., \& Aláč, P. (2015). Proposal for Optimization of Information System. Procedia Economics and Finance, 34, 477-484.

Fitrianah, D., \& Sucahyo, Y. G. (2012). Audit sistem informasi/teknologi informasi dengan kerangka kerja cobit untuk evaluasi manajemen teknologi informasi di universitas xyz. Jurnal SIstem Informasi, $4(1), \quad 37-46$. https://doi.org/https://doi.org/10.21609/jsi.v4i1.243

Hernandez, R. M. (2017). Impact of ICT on Education: Challenges and Perspectives. Propósitos y Representaciones, 5(1), 325-347. https://doi.org/10.20511/pyr2017

Hidayat, H., Hartono, \& Sukiman. (2017). Pengembangan Learning Management System (LMS) untuk Bahasa Pemrograman PHP. Jurnal Ilmiah Core IT: Community Research Information Technology, 5(1), 20-29. Retrieved from http://www.ijcoreit.org/index.php/coreit/article/viewFile/11/11

IKIP PGRI Pontianak. (2017). Pedoman Operasional IKIP PGRI Pontianak Tahun 2017/2018. Pontianak: IKIP PGRI Pontianak.

Janpla, S., Kularbphettong, K., Rattanachai, R., \& Tangtastham, K. (2015). The Development of Information Systems for the Traditional Occupation of the Local Community. Procedia - Social and Behavioral Sciences, 197(July 2018), 2526-2529. https://doi.org/10.1016/j.sbspro.2015.07.478

Lubanga, S., Chawinga, W. D., Majawa, F., \& Kapondera, S. (2018). Web Based Student Information Management System In Universities: Experiences From Mzuzu University. Standing Conference of Eastern, Central and Southern Africa Library and Information Associations (SCESCAL), (May), 655-669.

Lukman, A. M. (2017). Pengembangan Sistem Informasi Perpustakaan Umum Berbasis Web Menggunakan Inlislite 3.0 Di Kab. Enrekang. ILKOM Jurnal Ilmiah, 9(1), 70-77. https://doi.org/10.33096/ilkom.v9i1.112.70-77

Majid, N. W. A., Ridwan, T., Setiadi, B. R., \& Nurdiyanto, H. (2018). A comparative analysis: Web design of Universities in Indonesian and American Countries based on CNET and Hall theory. Proceedings of International Conference of Social Science (ICOSS 2018), (c). https://doi.org/10.4108/eai.21-9-2018.2281184 
Mansur, \& Kasmawi. (2017). Pengembangan Sistem Database Terpadu Berbasis Web Untuk Penyediaan Layanan Informasi Website Desa. Jurnal Nasional Teknologi Dan Sistem Informasi, 3(1), 73-82. https://doi.org/10.25077/teknosi.v3i1.2017.73-82

Muftia, Negara, A. B. P., \& Safiradi, N. (2015). Sistem Informasi Seminar dan Sidang Tugas Akhir Program Studi Teknik Informatika Universitas Tanjungpura. Jurnal Sistem Dan Teknologi Informasi (JUSTIN), 4(1), 128-132. Retrieved from http://jurnal.untan.ac.id/index.php/justin/article/view/12855/11650

Nur'Ainun, Hartono, \& Jimmy. (2017). Perancangan Aplikasi Mobile Repository Skripsi (Skripsi ALumni Mahasiswa) STMIK IBBI Medan Berbasis Android. Jurnal Ilmiah CORE IT, 5(2), 18-27. https://doi.org/10.30600/CIT.V5I2.29

Oluwatofunmi, A., Idowu, S. ., \& Izang, A. . (2018). Web-based Information System (WBIS) Framework: Facilitating Interoperability within Business Ventures. International Journal of Computer Applications, 180(26), 7-12. https://doi.org/10.5120/ijca2018916595

Ramayasa, I. P., \& Arnawa, I. B. K. S. (2015). Perancangan Sistem Monitoring Pengerjaan Skripsi Pada Stmik Stikom Bali Berbasis Web. Konferensi Nasional Sistem Dan Informatika, 760-765. Retrieved from https://pdfs.semanticscholar.org/4752/7e61c8ceb57f209080665654efb53ac5486e.pdf

Satyahadewi, N., \& Mutiah, N. (2019). Sistem Informasi Monitoring Tugas Akhir ( Simta ). (Journal of Computer Engineering System and Science, 4(1), 83-87.

Saxena, N. (2017). The Role and Impact of ICT in Improving the Quality of Education: An Overview. International Journal of Engineering Sciences \& Research Technology The, 6(3), 501-503.

Suendri. (2018). Implementasi Diagram UML (Unified Modelling Language) Pada Perancangan Sistem Informasi Remunerasi Dosen Dengan Database Oracle (Studi Kasus: UIN Sumatera Utara Medan). ALGORITMA: Jurnal Ilmu Komputer Dan Informatika, 3(1), 1-9. $\quad$ Retrieved from http://jurnal.uinsu.ac.id/index.php/algoritma/article/download/3148/1871

Sugiyono. (2009). Metode Penelitian Kuantitatif, Kualitatif, dan R\&D. Bandung: Alfabeta.

Sulindawaty. (2015). Implementasi Sistem Informasi Akademik Berbasis Web Pada Sekolah Menengah Pertama (SMP) Swasta Nusa Penida Medan. Jurnal Mantik Penusa, 18(2), 76-81. Retrieved from http://ejurnal.pelitanusantara.ac.id/index.php/mantik/article/view/133/54

Sulistiyarini, D., \& Sabirin, F. (2018). Analisis Perancangan Sistem Informasi Administrasi Program Studi Pendidikan Teknologi Informasi dan Komunikasi. Jurnal Penelitian Dan $\begin{array}{llll}\text { Pengembangan Sains Dan } 22 . & \end{array}$ https://doi.org/10.23887/jppsh.v2i1.14006

Surbakti, A., \& Pasaribu, S. (2018). Student Attendance Information System Design at SMK Swasta Satria 1 Binjai. Journal of Physics: Conference Series, 1114(1), 1-6. https://doi.org/10.1088/1742-6596/1114/1/012061

Susanti, M. (2016). Perancangan Sistem Informasi Akademik Berbasis Web Pada Smk Pasar Minggu Jakarta. Jurnal Informatika, 3(1), 91-99.

Wahyuniardi, R., Afrianti, L. H., Nurjaman, S., \& Gusdya, W. (2016). Sistem Informasi Berbasis Web Untuk Monitoring Dan Evaluasi. Jurnal Ilmiah Teknik Industri, 14(2), 174-186.

Wati, E. F., \& Kusumo, A. A. (2016). Penerapan Metode Unified Modeling Language (UML) Berbasis Desktop Pada Sistem Pengolahan Kas Kecil Studi Kasus Pada PT Indo Mada Yasa Tangerang. UNISKA Syntax Jurnal Informatika, 5(1), 24-36.

Williams, B., \& Sawyer, S. (2003). Using Information Technology. London: Grener Books. 